\title{
Attitudes Towards Blended Learning : A Study of Leadership Training Education (Diklat PIM) IV Year 2018 Training Participants
}

\author{
Nadya Megawati Rachman', Caterin Magdalena Simamora², \\ Ratnaningsih Hidayati ${ }^{3}$ \\ Center for Trade Education and Training, Ministry of Trade Republic of Indonesia ${ }^{1,2,3}$ \\ Email: nadya.megawati@kemendag.go.id ${ }^{1 *}$ \\ *corresponding author
}

\begin{abstract}
The advancement of information technology is one of the driving factors for implementing eGovernment. Nevertheless, the learning process in government official capacity development is now conceivably conducted online. This research aims to discover government officials' attitudes towards blended learning in a population of 40 respondents of Leadership Training Education or Diklat PIM IV in 2018. This research is conducted with a quantitative methodology approach. The T-test used to test the first research hypotheses. A one-way ANOVA was performed for examining the second and third hypotheses. The result shows there is a favorable attitude towards blended learning among the Diklat PIM IV 2018 training participants. There are significant differences in attitudes toward blended learning based on gender but there is no significant difference in attitudes towards blended learning based on age classification.
\end{abstract}

Keywords : age; attitude; blended learning; government officials; gender

\section{INTRODUCTION}

The Center for Trade Education and Training (CTET) is a division of the Ministry of Trade Republic (MOT) of Indonesia whose duty is to provide training for the MOT apparatus. Currently, the training program organized by the CTET is conducted in conventional methods, which is still based on face-to-face meetings in the classroom. On the other hand, the number of training that have not been able to meet the interest of enthusiasm of its stakeholders.

The advancement of information technology has now made it possible to conduct internet-based distance learning effectively and efficiently. Therefore, internet-based training in the form of blended learning or blended learning is a feasible practice and work as a solution in developing training programs at the CTET.

The announcement of Government Regulation, namely Peraturan LAN, concerning the implementation of leadership training with a new curriculum, brings the impact that the training institution has to be ready with the backbone internet infrastructure and facility. The leadership training curriculum requires the learning process to be carried out through a classical and non-classical learning approach. Conventional learning is carried out in the training center while in the non-classical learning, participants return to their respective institutions to communicate and implement the project. During the non-classical process, participants are facilitated with some guidance with their respective coaches. Coach is a training facilitator whose duty is to stimulate the thinking process and all the resources possessed by participants, build 
their self-awareness process and create various strategies to solve the problems they encounter with methods that have been proven through research. One of the tools that conceivably benefited in implementing the coaching process is to apply blended-learning approaches.

Government official capacity development through blended learning is not limited to non-classical learning; nonetheless, in classical learning, the use of information technology based-learning is possible in the blended learning format. Government regulation namely Peraturan Kepala LAN Nomor 5 tahun 2015 concerning Guidelines for the Implementation for Training Facilitators in Level III and IV Leadership Training ( Pedoman Penyelenggaraan Pelatihan Kewidyaiswaraan Substansi Pendidikan dan Pelatihan Kepemimpinan Tingkat III dan IV) stated that one of the teaching tutor competencies that must be possessed by the training facilitator is to be able to apply innovative learning methodologies in accordance with the training subjects. Web-based learning with the use of information technology considered to be an innovative breakthrough that is feasible to utilize because training participants are able to obtain a more comprehensive source of learning other than those provided by training facilitators in the classroom.

There has not been a firm definition of the term "e-learning." However, Richard \& Haya (2009) emphasize that internet has become an essential way to make available resources for research and learning for both teachers and students to share and acquire information. Wentling et al. (2000) explained that blended learning refers to the attainment and use of knowledge that is predominantly facilitated and distributed by electronic means. The e-learning rely upon computers and networks either they are internal or worldwide network, but it is likely it will progress into systems comprising of a variety of channels such as wireless and satellite, and technologies such as mobile phones

Twigg (2002) in Arkoful \& Abaidoo (2014) delineated the e-learning approach as focused on the learner in addition to its style as involving a system that's interactive, reiterative, self-paced, and customizable. Welsh et al. (2003) conjointly referred the term because of the use of network technology, chiefly through the net, to produce information and learning instruction to people.

European Commission (2001) describes e-learning as the use of new multimedia technologies and the Internet to increase learning quality by easing access to facilities and services. E-learning might as well improve distant exchanges and collaboration. OECD (2005) define blended learning as the use of information and communication technologies in varied processes of education to support and enhance the learning process in institutions of higher education (at the university or training institution) and includes the acceptance of information and communication technology as an addition to traditional classrooms, online learning or mixing the two modes of learning.

In the context of higher education or universities, according to Tao et al. (2006), this new atmosphere for learning that's focused on electronic networks has allowed learners in universities to receive personal support and conjointly to have learning schedules that are more appropriate to them additionally separate from different learners. This facilitates a high interaction and collaboration between instructors or academics and peers than the traditional atmosphere for learning. Liaw et al. (2007) in Arkoful \& Abaidoo (2014) described e-learning in higher education that is characterized by the utilization of multimedia constructs created the method of learning more active, 
attention-grabbing and enjoyable. The major constructs that have created e-learning the foremost promising academic technology, according to Hammer \& Champy (2001) and Liaw et al. (2007), consist of service, cost, quality, and speed. E-learning will empower students at higher academic levels to acquire their education in whereas at identical times perusal their objectives additionally as maintaining their own careers, with no need to attend to rigid schedule (Bottorff \& Lowe, 2007). Kartha, (2006), in support of this thought, believed that the quantity of courses online has vividly improved as a result of the attained advantages for each learner and universities.

Some researchers have discovered the relationship between age with online learning and student preference for types of online learning activities. Koh \& Lim (2012) studied the impact on academic performance once a web tool for collaborative work was utilized in a university engineering science course. Students within the class ranged in age from eighteen to twenty-six years old, and therefore the average age of the scholars within the course was 21.18. The researchers found that as the age of the student raised, the student's grade on the final project, conjointly increased. This study supports the thesis that older students score higher than younger students on measures of academic performance once web-based tools are utilized in a course.

Koh \& Lim (2012) conjointly studied the relationship between age, tutorial performance, and the social interaction afforded by completely different web-based collaborative tools. As the age of the student decreased, the student's preference for tools that allowed for additional online means that of communication enhanced. Younger students scored higher on the assignment after they may chat online, post photos, share stories, and share comments.

Several studies indicate that men and women dissent in their interaction with technology. Dorman, 1998; Kayany and Yelsma, 2000; Adamus et al., 2009 reported the sense of men being more prone to use computers and new media (Cuadrado-Garcia et al., 2010). In contrast, Cuadrado-Garcia et al. (2010) perform one-way and interindividual factor ANOVA analysis to test the existence of significant differences in the assessment and use of e-learning activities by male and female students in the context of an online project between two European universities. As a result, there are few differences between male and female students in their use of e-learning and their motivation and satisfaction. In another studies investigate the effectiveness of blended learning approach. The results mostly shows that blended learning meets educational needs of students, such as increasing convenience and flexibility and developing critical thinking (Ja'ashan, 2015).

\section{RESEARCH METHOD}

This research is conducted with a quantitative methodology approach. A population of training participants consists of 41 people who were surveyed to obtain the research objectives. It includes participants from different age groups and gender. The questionnaire was offered through the web-based survey on www.surveymonkey.com. The questionnaire is a 15-point questionnaire that measures blended learning attitudes (Cheng, 2006). This scale consists of three dimensions that measure, within an electronic educational system, individual perspective, learning effects and class management. In Cheng 's study the reported scale reliability alpha is 0.8076 .

Research Questions and Hypotheses: 
1. Are there significant negative attitudes toward blended learning from the training participants?

$\mathrm{HO}$ : There are no significant negative attitudes toward blended learning from the training participants

$\mathrm{H} 1$ : There are significant negative attitudes toward blended learning from the training participants

2. Is there any significant difference on attitude towards blended learning based on gender group?

$\mathrm{HO}$ : There will be no statistically significant difference in attitude towards blended learning based on gender group

$\mathrm{H} 1$ : There will be statistically significant difference in attitude towards blended learning based on gender group

3. Is there any significant difference on attitude towards blended learning based on age group?

$\mathrm{HO}$ : There will be no statistically significant difference in attitude towards blended learning based on age group

$\mathrm{H} 1$ : There will be statistically significant difference in attitude towards blended learning based on age group

\section{RESULT AND DISCUSSION}

\section{Descriptive Analysis}

Of the 40 trainees, the responses obtained were 100\%; all the trainees filled out questionnaires through links shared in Edmodo Learning Management System. Some participants have had experience in participating in online based learning held by several institutions, namely WTO, Edx, Coursera, Vrije University, and others.

The data were grouped according to different factors such as gender and age (Table 1 and 2).

Table 1. Descriptive statistics based on gender

\begin{tabular}{|l|l|l|}
\hline Gender & Frequency & Percent \\
\hline Male & 23 & 57.5 \\
\hline Female & 17 & 42.5 \\
\hline Total & 40 & 100 \\
\hline
\end{tabular}

Source : Primary data, 2018

Table 2. Descriptive statistics based on age

\begin{tabular}{|l|l|l|l|l|}
\hline Gender & Minimum & Maximum & Mean & Standard Deviation \\
\hline Age & 29 & 53 & 36,7561 & 4,30569 \\
\hline
\end{tabular}

Source : Primary data, 2018

\section{Hypotheses Testing}

\section{Negative attitudes toward blended learning}

The T-test will be used to test the research hypotheses to compare the mean scores of two different groups of people or conditions. In this research we compare the mean score with the hypothetical mean of the scale.

$\mathrm{HO}$ : There are significant negative attitudes toward blended learning from the training participants 
$\mathrm{H} 1$ : There are no significant negative attitudes toward blended learning from the training participant

Blended learning is relatively new in the context of Indonesia. Nevertheless, the training participants have been familiar with this system, particularly the elearning part, because they have enrolled and were admitted to the e-learning class held by other institutions. Therefore, the authors expected that there would not be significant negative attitudes towards blended learning. In other words, participants are ready to learn with this new system. The descriptive statistics for the scale items are presented in table 3 and then tested whether the score items differ significantly from the theoretical scale mean (4 points on the Likert-type scale). Descriptive statistics help us to simplify large amounts of data in a sensible way.

Table 3. Descriptive statistics

\begin{tabular}{|l|l|l|l|l|l|l|l|l|l|}
\hline & Mean & $\begin{array}{l}\text { Standard } \\
\text { Error }\end{array}$ & Median & Mode & $\begin{array}{l}\text { Standard } \\
\text { Deviation }\end{array}$ & $\begin{array}{l}\text { Sample } \\
\text { Variance }\end{array}$ & Range & Min & Max \\
\hline Q1 & 3,0976 & 0,0976 & 3 & 3 & 0,6247 & 0,3902 & 2 & 2 & 4 \\
\hline Q2 & 3,2683 & 0,0857 & 3 & 3 & 0,5488 & 0,3012 & 2 & 2 & 4 \\
\hline Q3 & 3,1951 & 0,0871 & 3 & 3 & 0,5577 & 0,3110 & 2 & 2 & 4 \\
\hline Q4 & 3,1707 & 0,0917 & 3 & 3 & 0,5875 & 0,3451 & 2 & 2 & 4 \\
\hline Q5 & 3,2439 & 0,0840 & 3 & 3 & 0,5376 & 0,2890 & 2 & 2 & 4 \\
\hline Q6 & 3,1707 & 0,0848 & 3 & 3 & 0,5433 & 0,2951 & 2 & 2 & 4 \\
\hline Q7 & 3,2250 & 0,0839 & 3 & 3 & 0,5305 & 0,2814 & 2 & 2 & 4 \\
\hline Q8 & 3,1220 & 0,1059 & 3 & 3 & 0,6781 & 0,4598 & 3 & 1 & 4 \\
\hline Q9 & 3,2439 & 0,0764 & 3 & 3 & 0,4889 & 0,2390 & 2 & 2 & 4 \\
\hline Q10 & 3,0976 & 0,0765 & 3 & 3 & 0,4901 & 0,2402 & 2 & 2 & 4 \\
\hline Q11 & 3,0000 & 0,1048 & 3 & 3 & 0,6708 & 0,4500 & 2 & 2 & 4 \\
\hline Q12 & 3,0732 & 0,1012 & 3 & 3 & 0,6477 & 0,4195 & 3 & 1 & 4 \\
\hline Q13 & 3,2927 & 0,0873 & 3 & 3 & 0,5587 & 0,3122 & 2 & 2 & 4 \\
\hline Q14 & 3,2683 & 0,0989 & 3 & 3 & 0,6334 & 0,4012 & 2 & 2 & 4 \\
\hline Q15 & 3,1707 & 0,1042 & 3 & 3 & 0,6672 & 0,4451 & 3 & 1 & 4 \\
\hline
\end{tabular}

Source : Primary data, 2018

The T-test was performed to test the hypotheses (see table 4).

Table 4. Two-tailed one sample T-test Results

\begin{tabular}{|l|l|l|l|l|l|}
\hline & Mean & Variance & df & t Stat & P(T<=t) two-tail \\
\hline$Q 1$ & 3,097561 & 0,390244 & 40 & $\mathbf{6 , 1 2 5}$ & $3,15334 \mathrm{E}-07$ \\
\hline$Q 2$ & 3,268293 & 0,30122 & 40 & $\mathbf{8 , 9 6 3 4 8 9}$ & $4,10792 \mathrm{E}-11$ \\
\hline$Q 3$ & 3,195122 & 0,310976 & 40 & $\mathbf{7 , 9 8 1 5 9 6}$ & $8,37265 \mathrm{E}-10$ \\
\hline$Q 4$ & 3,170732 & 0,345122 & 40 & $\mathbf{7 , 3 1 0 6 2 4}$ & $6,9525 \mathrm{E}-09$ \\
\hline$Q 5$ & 3,243902 & 0,289024 & 40 & $\mathbf{8 , 8 6 0 1 4 2}$ & $5,61269 \mathrm{E}-11$ \\
\hline$Q 6$ & 3,170732 & 0,295122 & 40 & $\mathbf{7 , 9 0 5 6 9 4}$ & $1,06156 \mathrm{E}-09$ \\
\hline$Q 7$ & 3,225 & 0,28141 & 40 & $\mathbf{8 , 6 4 3 6 6 7}$ & $1,33944 \mathrm{E}-10$ \\
\hline
\end{tabular}




\begin{tabular}{|l|l|l|l|l|l|}
\hline$Q 8$ & 3,121951 & 0,459756 & 40 & $\mathbf{5 , 8 7 3 3 3 1}$ & $7,12239 \mathrm{E}-07$ \\
\hline$Q 9$ & 3,243902 & 0,239024 & 40 & $\mathbf{9 , 7 4 2 8 6 8}$ & $4,07141 \mathrm{E}-12$ \\
\hline$Q 10$ & 3,097561 & 0,240244 & 40 & $\mathbf{7 , 8 0 6 3 4 9}$ & $1,44956 \mathrm{E}-09$ \\
\hline$Q 11$ & 3 & 0,45 & 40 & $\mathbf{4 , 7 7 2 6 0 7}$ & $2,43664 \mathrm{E}-05$ \\
\hline$Q 12$ & 3,073171 & 0,419512 & 40 & $\mathbf{5 , 6 6 6 3 5 3}$ & $1,39119 \mathrm{E}-06$ \\
\hline$Q 13$ & 3,292683 & 0,312195 & 40 & $\mathbf{9 , 0 8 4 0 2 6}$ & $2,85911 \mathrm{E}-11$ \\
\hline$Q 14$ & 3,268293 & 0,40122 & 40 & $\mathbf{7 , 7 6 6 5 4}$ & $1,64273 \mathrm{E}-09$ \\
\hline$Q 15$ & 3,170732 & 0,445122 & 40 & $\mathbf{6 , 4 3 7 2 6 3}$ & $1,14826 \mathrm{E}-07$ \\
\hline
\end{tabular}

Source: Primary Data, 2018

Table 4 shows that all the scores on all the items are significantly higher than the scales' theoretical mean. This result supports $\mathrm{HO}$, which states that training participants have no negative attitudes towards a blended learning approach. From this research finding, we can thus conclude that there is a favourable attitude towards blended learning among the PIM IV 2018 training participants. This point is also highlighted by Mezileveska (2007) who concludes that students generally have positive attitude towards blended model of learning, noting that they still use traditional approach as the simplest for discussions on the content and for receiving feedback from the teacher. The traditional teaching has to be adjusted to the needs of the new "digitally literate" students. The findings confirm the research that the facilitators acquire advantages relatively quickly and easily, thus indirectly they point out the principle of collaborative teaching in pedagogical work. Moreover, the blended learning model can improve the outcomes of learning, increase student satisfaction, and make subject more accessible to a wider range of students (Eshreteh \& Siaj, 2017).

\section{Attitude towards blended learning based on gender group}

In examining the second hypothesis, a one-way ANOVA test was performed. The results are presented in Table 5.

Table 5. ANOVA result on attitudes towards blended learning between male and female participants.

\begin{tabular}{|l|l|l|l|l|l|l|}
\hline ANOVA \\
\hline Source of Variation & $S S$ & $d f$ & $M S$ & $F$ & $P$-value & F crit \\
\hline Between Groups & 280,3604 & 1 & 280,3604 & 10,348 & $\mathbf{0 , 0 0 2 6 5}$ & 4,0982 \\
\hline Within Groups & 1029,54 & 38 & 27,09315 & & & \\
\hline Total & 1309,9 & 39 & & & & \\
\hline
\end{tabular}

Source: Primary Data, 2018 Analyzed

The results indicate that there is significant difference in attitudes towards blended learning between male and female participants. The Analysis of Variance (ANOVA) resulted the P-value below the critical value of 0,05 and $F$ above the critical Fvalue. Koohang's (2004) study regarding gender, find out that male were more inclined to use blended learning environment than female. This also confirms the finding of Birbal et al. (2018), the t-test result showed that there was a significant difference between male and female attitudes on online learning. Male students had a more positive attitude 
towards online learning than female students. Al-Fadhli (2008) also reported a strong significant in students' attitude toward e-learning in accordance with gender. Female students' mean score outscored their male counterparts in all areas. Female students were obviously positive in evaluating elements of the course. Abou Naaj et al. (2012) in a study of evaluating student satisfaction with blended learning in a gender-segregated environment find out that male students are more satisfied with blended learning than female students. According to Meyer (2003), gender is distinctive and plays an important role in online interactions and exchanges similar to reality. He has pointed out that females are more sympathetic, amenable, and well- mannered. However, males were more controlling of the online exchanges, more inquisitive, and assertive.

In another research, this fact contrasts with Cuadrado-Garcia et al. (2010) that there are few differences between male and female students in their use of blended learning and their motivation and satisfaction in the context of European Universities. AlZumor et al. (2013) in a study of Egyptian EFL Student also take a similar position, students' gender had a significant effect on students' learning style but it had no bearing on their satisfaction with web-based materials. Askar et al. (2008) reported no statistically siginificant differences were found between females and males with respect to the satisfaction on blended learning; however female scores were statistically higher than the males for the face to face environment. Adas \& Abu Shmais (2011) also found there are no significant differences in terms of gender even though the highest means were in favour of females.

\section{Atittude towards blended learning based on age group}

In examining the third hypothesis, a one-way ANOVA test was performed. The results are presented in Table 6.

Table 6. ANOVA result on attitudes towards blended learning based on Age Group

\begin{tabular}{|l|l|l|l|l|l|l|}
\hline ANOVA \\
\hline Source of Variation & $S S$ & $d f$ & $M S$ & $F$ & P-value & F crit \\
\hline Between Groups & 118,8762 & 1 & 118,8762 & 3,792783 & $\mathbf{0 , 0 5 8 3 9 1}$ & 4,098172 \\
\hline Within Groups & 1191,024 & 38 & 31,34273 & & & \\
\hline Total & 1309,9 & 39 & & & & \\
\hline
\end{tabular}

Source: Primary Data, 2018 Analyzed

The Analysis of Variance (ANOVA) resulted the F-value below the critical F and $P$-sign above the critical value of 0,05 . The results indicate no significant difference in attitudes towards blended learning based on age group. Millennials, also known as Generation Y (or simply Gen Y), are the demographic cohort following Generation X and preceding Generation Z. Researchers and popular media use the early 1980 s as starting birth years and the mid-1990s to early 2000s as ending birth years, with 1981 to 1996 a widely accepted defining range for the generation. In this research, $80.4 \%$ of participant are millennial. However, Khechine et al. (2014), in a studies of UTAUT Model for Blended Learning: The Role of Gender and Age in the Intention to Use Webinars, report that the positive effect of performance expectancy on the intention to use e-learning was moderated by age, such that the effect was more salient for younger students. Numerous studies have reported that age was a significant contributor to the performance differences between traditional and online/distance learning students (e.g., Schultz, 
Schultz, \& Round, 2010). Previous research had also shown that younger workers were proven to be more interested in performance expectancy than older ones (Venkatesh et al., 2003). Birbal et al. (2018) also found that the Results of the analysis of variance indicated significant differences according to age groups for online learning and online environment factor. This study revealed that younger students had less positive views than older students with regard to online learning.

\section{CONCLUSION}

The present study contributed to reveal the students' perception and attitude about blended learning for PIM IV Training Participant. The results of this study illustrate the students' satisfaction with Blended Learning as it enhance training to be more collaborative, interactive and interesting. Moreover, this reflects the interaction between facilitators and participant, and gives them enough time to do their tasks. So, participant are encouraged to take responsibility for their own learning process and learners can decide when and how to use the resources provided. It can enhance educational reform by creating a paradigm shift from teacher-centered and memory-based education to a student-centered education where students work collaboratively, construct their own knowledge and enhance their critical thinking. In this study, it is worth to mention that blended learning is still in the developmental stage at Center Trade and Education Training Center (CTET). It needs more research and development that address types of blended learning from different aspects such as effective infrastructure and training of both instructors/facilitators and learners with efficient skills in teaching and learning. Implication of this paper is based on the findings that emerged from the data analysis. The researcher suggest a research to adopt general methodology developed in Blended Learning for another training that held at CTET.

\section{BIBLIOGRAPHY}

Abou Naaj, M., Nachouki, M., \& Ankit, A. (2012). Evaluating Student Satisfaction with Blended Learning in a Gender-Segregated Environment. Journal of Information Technology Education : Research, 11, $185-200$.

Adas, D., \& Abu Shmais, W. (2011). Students perceptions towards blended learning environment using the OCC. An-Najah University Journal for Research Humanities, 25(6), 1681-1710.

Al-Fadhli, S. (2008). Students perceptions of e-learning in Arab society: Kuwait University as a case study. E-Learning and Digital Media, 5(4), 418-428.

Al-Zumor, Abdul, W. Q., Ismail, K. A.-R., Eyhab, A. B. E., \& Farouq, H. A. A.-R. (2013). EFL Students of a Blended Learning Environment. English Language Teaching, 6(10), 95-110.

Arkoful, V., \& Abaidoo, N. (2014). The Role of blended learning, the advantages and disadvantages of its adoption in higher education December 2014. International Journal of Education and Research, 2(12).

Askar, P., Altun, A., \& Ilgaz, H. (2008). Learner satisfaction on blended learning. E-leader conference.

Birbal, R., Ramdass, M., \& Harripaul, C. (2018). Student Teachers' Attitudes towards Blended Learning. Journal of Education and Human Development, 7(2), 9-26.

Bottorff, P. C., \& Lowe, S. L. (2007). Student perceptions and opinions toward blended learning in the college environment. Academy of Educational Leadership Journal, 10(7), 13-30.

Cuadrado-Garcia, M., Ruiz-Molina, M., \& Montoro-Pons, J. (2010). Are there gender differences in blended learning use and assessment? Evidence from an 
interuniversity online project in Europe. In Procedia Social and Behavioral Sciences 2.

Eshreteh, M. K. M., \& Siaj, A. H. (2017). Attitudes of English-Major Students and Teachers towards Using Blended Learning in the English Department at Hebron University. International Journal of Research in English Education, 2(4), 51-65.

European Commission. (2001). The eLearning Action Plan: Designing tomorrow's education. http://www.elearningeuropa.info

Hammer, M., \& Champy, J. (2001). Re-engineering the Corporation. Harpercollins.

Kartha, C. P. (2006). Learning business statistics vs. traditional. Business Review, 5, 27-33.

Khechine, H., Pascot, D., Lakhal, S., \& A., B. (2014). UTAUT model for blended learning: the role of gender and age in the intention to use webinars Retrieved from. Interdisciplinary Journal of E-Learning and Learning Objects, 10, 33-52. http://www.ijello.org/Volume10/IJELLOv10p033-052Khechine0876.pdf

Koh, E., \& Lim, J. (2012). Using online collaboration applications for group assignments: The interplay between design and human characteristics. Computers and Education, 59, 481-496.

Koohang, A. (2004). Students' perceptions toward the use of the digital library in weekly web-based distance learning assignments portion of a hybrid program. British Journal of Educational Technology, 35, 617-626.

Mezileveska, I. (2007). Transnational education programs: Student reflections on a fullyonline versus a hybrid model. Victoria University.

Meyer, K. A. (2003). The Web's Impact on Student Learning. T.H.E. Journal, 30(10). https://www.learntechlib.org/p/97482/

OECD. (2005). Blended learning in tertiary education [Online]. http://www.oecd.org/education/ceri/35991871.pdf

Richard, H., \& Haya, A. (2009). Examining student decision to adopt web 2.0 technologies: theory and empirical tests. Journal of Computing in Higher Education, 21(3), 183-198.

Tao, Y. H., Yeh, C. R., \& Sun, S. I. (2006). Improving training needs assessment processes via the Internet: system design and qualitative study. Internet Research, 16(4), 427-449.

Twigg, C. (2002). Quality, cost, and access: the case for redesign. In The Wired Tower. (Pittinsky,). Prentice-Hall.

Venkatesh, V., Morris, M. G., Davis, G. B., \& Davis, F. D. (2003). User acceptance of information technology: Toward a unified view. MIS Quarterly, 27(3), 425-478.

Wentling, T. L., Waight, C., Gallagher, J., La Fleur, J., Wang, C., \& Kanfer, A. (2000). Blended learning - a review of literature. In Knowledge and Learning Systems Group NCSA 9 (pp. 1-73). 